\title{
Effects of Different Cultivation Practices and Postharvest Treatments on Tomato Quality
}

\author{
Meaza Melkamu, Tilahun Seyoum* and Kebede Woldetsadik
}

Haramaya University, College of Agriculture, P O Box 138, Dira Dawa, Ethiopia

\begin{abstract}
The present investigation was aimed at evaluating the combined effect of pre- and postharvest treatments on the quality of tomato (Lycopersicon esculentum Mill). The preharvest treatments used were ComCat ${ }^{\mathbb{R}}$, manure, NP and the combinations of ComCat ${ }^{\mathbb{B}}$ with the two forms of fertilizers and a control. These preharvest treatments were combined with three disinfection and two storage treatments. The tomatoes were periodically analyzed for weight loss, total soluble solids, $\mathrm{pH}$, titratable acidity, ascorbic acid and marketability. Preharvest ComCat ${ }^{\circledR}$ and ComCat ${ }^{\circledR}+$ manure treatments improved the quality of tomato during storage. During the storage period, ComCat ${ }^{\circledR}$ reduced weight loss, better maintained the chemical compositions and marketability of the tomatoes. Manure treated tomatoes had higher ascorbic acid content during the storage period. Tomatoes stored using evaporative cooling system remained marketable up to the 28 days compered to a maximum of 16 days of ambient storage conditions. Storage at ambient conditions resulted in higher weight loss and rapid change in chemical composition that resulted in quality deterioration of tomatoes. Disinfecting treatments had significant $(\mathrm{P}$ $<0.01)$ effects on weight loss of tomatoes during storage. Two-way interactions between preharvest and storage conditions were significant $(\mathrm{P}<0.05)$ in terms of the various physiological and chemical parameters of tomatoes. In general, the benefits of the combined effect of preharvest treatments and evaporatively cooled storage on tomatoes included reduction in the weight loss and total soluble solids, maintenance of higher titratable acidity, ascorbic acid and marketabilityof tomatoes.
\end{abstract}

Keywords: Biocatalyst; Disinfection; Evaporative Cooling; Fertilizer; Quality; Tomato

\section{Introduction}

Postharvest physiological, microbiological and chemical qualities of tomatoes partly depend up on preharvest factors such as genetic, environmental conditions and management (Hobson, 1964). Cultural practices such as nutrient and water supply and harvesting methods are also claimed to be factors influencing tomato quality after harvest (Watkins and Pritts, 2001). Application of mineral fertilizers, especially of nitrogen, affects the chemical composition of vegetables including tomato (Watkins and Pritts, 2001). Similarly, application of organic fertilizer makes it possible to obtain high and good quality yields of vegetables and replenish soil fertility degeradation (Fichter, 1986). Recent research findings suggested the possibility of natural plants species, in which their biostimulatory activity (Schenabel et al., 2000; Seyoum, 2002). As a result, ComCat ${ }^{\circledR}$ was one of the plant procuct developed as a natural product with its plant strengthening properties and the ability to improve growth and yield in different agricultural crops including tomato. The treatment consists of biocatalysts of plant origin and induces resistance via activating plant defence mechanisms against pathogens, and biotical and abiotical stress factors (Schenabel et al., 2000). It is is an alternative to chemical treatments and can fit into future research trends to have a balance between yield and ecologisation. Many postharvest losses are influenced by factors before harvest (Booth, 1978). For example, fruit and vegetables that are infected with pests and diseases, inappropriately irrigated and fertilized, or management can never be improved by postharvest treatments (Harvey, 1978). Very often, the rate of commodity loss is faster if the quality at harvest is below standard. Unlike the other preharvest chemical treatments ComCat $^{\circledR}$ is that it is both environmentally and ecologically friendly. However, at present there is no information on the postharvest quality aspects of $\mathrm{ComCat}^{\circledR}$ treated vegetables. The following questions arise: how do these complex plant growth regulators and natural metabolites affect the quality of tomatoes at harvest?

The microbial load associated with tomatoes during storage plays an important role on quality deterioration (Brackett, 1990). Chlorine treatments were found to be effective in reducing the occurrence of post harvest decay by pathogens (Prusky et al., 2001) and hot water washing was also found to be very efficient to control postharvest decay in fruit and vegetables (Fallik et al., 1999). Regarding extended shelf life, literature pointed out low storage temperature and high relative humidity is preferable for best results (Seyoum and Woldetsadik, 2004). A cooling chamber that works on the principle of evaporative cooling was developed to alleviate postharvest loss of fruit and vegetables. Generally, quality and duration of shelf life of fruit and vegetables are affected by the combined effect of preharvest and postharvest treatments. Therefore, the increase in yield of tomato due to some of the prehatvest treatments needs to be necessarily accompanied by the use of appropriate techniques that minimize postharvest loss. Thus, in this paper the effect of preharvest ComCat ${ }^{\circledR}$, manure, NP, combinations of $\mathrm{ComCat}^{\circledR}$ with the two forms of fertilizers and postharvest treatments such as dipping in chlorinated water, dipping in hot water, storage under evaporatively cooled storage and ambient conditions on 
weight loss, total soluble solid, $\mathrm{pH}$, titratable acidity, ascorbic acid and marketability of tomato are reported.

\section{Materials and Methods}

\subsection{Site Description}

The field experiment was conducted at the farm of Haramaya University in Dire Dawa during the period from September to January, 2004/2005. The Farm is located at an altitude of $1197 \mathrm{~m}$ above sea level and lies at 9० 6' $\mathrm{N}$ latitude and 41. 8' $\mathrm{E}$ longitude in the eastern part of Ethiopia. The station lies in the semi-arid belt of the eastern rift valley escarpment with a long-term average rainfall of $612 \mathrm{~mm}$. The mean annual rainfall is $520 \mathrm{~mm}$ and mean maximum and minimum temperatures range from $28.1^{\circ} \mathrm{C}$ to $34.6^{\circ} \mathrm{C}$ and $14.5^{\circ} \mathrm{C}$ to $21.6^{\circ} \mathrm{C}$, respectively (Belay, 2002). The soil is classified as Eutric Regosol with a gentle slop (3-8\%) (Tesfaye, 2004). The texture and structure of the topsoil $(0-30 \mathrm{~cm})$ are sandy loam and sub angular blocky, respectively. The soil has an average $\mathrm{pH}$ $\left(\mathrm{H}_{2} \mathrm{O} 1: 2.5\right)$ of 8.54 and organic matter content of $1.94 \%$ $(0-15 \mathrm{~cm})$ and $1.84 \%(15-30 \mathrm{~cm})$ (Tesfaye, 2004).

\subsection{Sample Production}

Fresh tomato variety, Marglobe, was raised in glass house at Haramaya University campus for about two weeks from July 30 to August 16, 2004 and were pricked for another two weeks in the field from August 17 to September, 2004. The plots prepared consisted of six rows $0.75 \mathrm{~m}$ apart, spaced $0.5 \mathrm{~m}$ apart in the row with 90 plants per plot. The net area of the experimental field was $875.75 \mathrm{~m}^{2}$.

The experiment was conducted in a randomized complete block design with three replications per treatment. The inorganic fertilizer, diammonium phosphate (DAP) and urea were applied to each plot at the rate of $200 \mathrm{~kg} \mathrm{ha}^{-1}$ and $150 \mathrm{~kg} \mathrm{ha}^{-1}$ respectively. The rate of organic fertilizer (manure) was 20 tons per hectare. Organic fertilizer (manure), DAP and half of the nitrogen fertilizer were incorporated to the experimental plots before planting while the rest was applied two weeks after the establishment of seedlings. ComCat ${ }^{\circledR}$ was applied at $100 \mathrm{~g} \mathrm{ha}^{-1}$ in $350 \mathrm{~L}$ and sprayed twice during the growth period. First spray was just prior to transplanting of seedlings while the second was carried out before flowering as recommended by Huster (2001). Other agronomic practices were applied as needed during the growth season uniformly to all plots. Plots were irrigated every other day for the first two weeks and then at weekly interval.

\subsection{Sample Preparation}

Green mature tomato fruit were harvested from each plot that was subjected to different preharvest treatments. Harvesting was carried out manually with care to minimize mechanical injury. Data on quality parameters were recorded from the central four rows of randomly selected plants. Uniform unblemished fruit having similar size and color were selected and hand washed with tap water.

To determine quality of fresh market tomato at harvest (0 day storage) six green mature tomatoes were randomly selected from each plot and were analyzed for six chemical parameters after disinfection treatments. For analysis during storage, washed fruit were subdivided into three groups of $288 \mathrm{~kg}$ each, in preparation for dipping treatments. Plastic containers were washed and rinsed with distilled water prior to use for the dipping treatments. The disinfection treatments consisted of chlorinated water, hot water at $52^{\circ} \mathrm{C}$ and tap water $\left(23^{\circ} \mathrm{C}\right)$ dipping as control.

For the chlorinated water dipping treatment, tap water was adjusted to $100 \square \mathrm{g} \mathrm{ml}^{-1}$ total chlorine with standard grade sodium hypochlorite $(5 \% \mathrm{NaOCl})$ and tomato was dipped for 20 minute (Seyoum et al., 2003). The free chlorine was determined using a test kit from Hach (Model CN-66; USA). The temperature was maintained at $4^{\circ} \mathrm{C}$ during the measurements of total chlorine. A 20 minute dipping time in $100 \mu \mathrm{g} \mathrm{ml} \mathrm{ml}^{-1}$ chlorine supplemented water solutions was selected, as this was reported to be the optimum effective concentration and dipping time without significant effect on the overall quality of fruit and vegetables (Nunes and Emond, 1999). The hot water dipping treatment included dipping tomatoes in hot water at $52^{\circ} \mathrm{C}$ for five minutes. Dipping tomato fruit in tap water $\left(24.2^{\circ} \mathrm{C}\right)$ for 20 minute was used as control treatment. After the disinfecting treatment, the disinfected fruit were again subdivided and stored in evaporatively cooled storage $(432 \mathrm{~kg})$ and at ambient conditions (432 kg) in three replications in a $1 \mathrm{~kg}$ unit. A total amount of $864 \mathrm{~kg}$ tomatoes were used in the study.

\subsection{Experimental Design}

A factorial combination of six preharvest, three disinfecting and two storage treatments with 3 replications were used in the study. The treatments were arranged in a randomized complete block design. On each sampling date, a sample of tomatoes was randomly taken from each treatment for quality analysis. On each sampling date, a sample of 5 tomato fruit from evaporatively cooled and ambient storage in each treatment was randomly taken for assessment. Data were recorded on 0, 4, 8, 12, 16, 20, 24 and 28 days after storage.

\subsection{Evaporative Cooling System}

The evaporative cooling system developed by Seyoum and Woldetsadik (2004) was used as storage chamber in this study. The evaporative cooling chamber maintained lower temperature $\left(14.3-19.3^{\circ} \mathrm{C}\right)$ and higher relative humidity (70.2-82.4\%). On the other hand, the ambient temperature and relative humidity ranging from $25.2-32.1^{\circ} \mathrm{C}$ and $32.2-$ $50.6 \%$, respectively, were recorded during the storage. 


\subsection{Chemical Analysis}

Weight loss was determined using the methods described by Waskar et al. (1999). The physiological weight loss was calculated for each interval and converted into percentage of initial weight. The cumulative weight loss was expressed in percentage with respect to different treatments. Total soluble olids (TSS) were determined following the procedures described by Waskar et al. (1999). An aliquot of juice was extracted using a juice extractor (Type 6001x, USA), according to Nunes and Emond (1999). An Atago $\mathrm{N}$, hand refractometer with a range of 0 to $32^{\circ} \mathrm{Brix}$ and resolutions of $0.2^{\circ}$ Brix was used to determine TSS by placing 2-3 drops of clear juice on the prism. The ascorbic acid content of the fruit was determined by the 2, 6dichlorophenol indophenols method (AOAC 1970). The aliquot of $10 \mathrm{ml}$ tomato juice was diluted to $50 \mathrm{ml}$ with 3 percent metaphosphoric acid in a $50 \mathrm{ml}$ volumetric flask. The aliquot was titrated with the standard dye to a pink end point (persisting for 15 second). The ascorbic acid (AA) content was calculated from the titration value, dye factor and volume of the sample. The $\mathrm{pH}$ value of the tomato juice was measured with a $\mathrm{pH}$ meter. The titratable acidity (TA) of tomato was measured according to the methods described by Maul et al. (2000). An aliquot of tomato juice was extracted from the sampled tomato with the juice extractor (6001x model No. 31JE35 6x.00777) and filtered through cheese cloth. Decanted clear juice was used for the analysis. The TA, expressed as percentage citric acid, was obtained by titrating $10 \mathrm{ml}$ of tomato juice with $0.1 \mathrm{~N} \mathrm{NaOH}$ to $\mathrm{pH} 8.2$.

\subsection{Subjective Quality Analysis}

The marketable quality of tomato fruit was subjectively assessed according to Mohammed et al. (1999). The descriptive quality attributes were determined by observing the level of visible mould growth, decay, shriveling or dehydration, colour and the surface appearance characteristics such as smoothness and shine of the fruit.

\subsection{Statistical Analysis}

All the data were analysed according to Gomez and Gomez (1984). ANOVA was carried out with an MSTATC soft ware package (MSTAT, USA). Comparisons of the treatment means were done using Duncan's Multiple Range Test (Duncan 1955).

\section{Results and Discussion 3.1. Weight Loss}

Preharvest treatment, storage temperature and their interaction had significant $(\mathrm{P}<0.01)$ effect on the weight loss of tomatoes (Table 1). However, disinfection treatments showed nonsignificant $(\mathrm{P}>0.05)$ effect till the end of day 12. ComCat ${ }^{\circledR}$ treatment significantly $(\mathrm{P}<$ 0.01) lowered WL than all the other preharvest treatments (see day 28 data in Table 1). The control tomatoes had the highest WL on the $28^{\text {th }}$ days of storage. The preharvest $\mathrm{ComCat}^{\circledR}+$ manure and $\mathrm{ComCat}^{\circledR}+\mathrm{NP}$ treatments also resulted in significantly $(\mathrm{P}<0.01)$ lower WL than manure, NP and control treatments from day 12 onwards. Tomatoes subjected to preharvest manure, NP and control treatments had higher $(\mathrm{P}<0.01)$ WL towards the end of storage periods. Literature has shown that excessive fertilization resulted in increased weight loss in sweet potato during storage (Mark et al. 2003), which seems to agree with the results in this study. The combination of $\mathrm{ComCat}^{\circledR}$ with the two forms of fertilizers reduced WL but not as ComCat ${ }^{\circledR}$ did alone. On day 28, WL significantly $(\mathrm{P}<0.01$ ) reduced by $12.7 \%$, $8.5 \%$ and $6.68 \%$ in ComCat $^{\circledR}$, ComCat $^{\circledR}+$ manure and $\mathrm{ComCat}^{\circledR}+\mathrm{NP}$ treated tomatoes when compared to control tomatoes, respectively.

Weight loss was not significantely $(\mathrm{P}>0.05)$ affected by the disinfection treatments up to day 12; however, disinfection had significant $(\mathrm{P}<0.01)$ effect on WL thereafter. The tomato fruit dipped in chlorinated water had significantly $(\mathrm{P}<0.01)$ higher $\mathrm{WL}$ starting from day 16 until day 24 of the storage period when compared to tomato fruit dipped in hot and tap water. The relatively higher WL associated with tomato fruit dipped in chlorinated water compared to hot water treated fruit could be attributed to the itching effect of chlorine solution on the skin of the fruit and surface tissues which is in agreement with the finding of Seyoum et al. (2003). Storage environment had significant $(\mathrm{P}<0.001)$ effect on the weight loss of tomato fruit during storage as shown in Table 1. WL slowly increased in tomatoes stored using the evaporative cooling system comered to a rapid rate of increase in tomatoes stored at ambient conditions. Tomatoes stored at ambient conditions suffered about two times more weight loss than those stored at cool storage. High temperature increases the vapour pressure difference between the fruit and the surrounding, which is the driving potential for faster moisture transfer from the tomato fruit to the surrounding air (Kader 1985 and Salunkhe et al., 1991). The reduction in WL of tomato at EC storage in the present work agrees with previous reports for mango fruit (Waskar et al., 1991; Pal and Roy 1991). The two-way interaction between preharvest and storage treatments significantly $(\mathrm{P}<0.001)$ affected WL during the storage. Similarly, the three-way interaction showed significant $(\mathrm{P}<0.01)$ effect on $\mathrm{WL}$ after 16 days of storage. This data clearly demonstrated the importance of integerated agro-technology on the shelf life improvement of tomatoes.

\subsection{Total Soluble Solids}

The total soluble solid (TSS) values varied between 4.07 and 5.60 oBrix. At harvest, the green mature ComCat ${ }^{\circledR}$ treated tomatoes contained significantly $(\mathrm{P}<0.01)$ higher TSS when compared with NP, ComCat ${ }^{\circledR}+\mathrm{NP}$ and $\mathrm{ComCat}^{\circledR}+$ manure treated tomato fruit. However, it did 
not show significant difference $(\mathrm{p}>0.01)$ when it is compared with control and manure treated tomatoes.

At harvest, manure treated tomatoes had higher TSS when compared to tomatoes subjected to NP treatment. This increase in the TSS content of manure treated tomatoes might be due to the higher photosynthetic efficiency by the relatively larger and broader leaves and increase of fruit sink strength in manure treated tomatoes. Raupp (1996) reported the positive effect of manure on TSS content of vegetables whereas Mccollum et al. (2004) found little difference in soluble solids between conventional grown and organically grown fruit. Among the preharvest treatments, only ComCat ${ }^{\circledR}+\mathrm{NP}$ treatment significantly $(\mathrm{p}<0.01)$ decreased the TSS content of tomato at harvest compared with control, which agrees with the findings of Hegde and Srinivas (1990) and Karaman (1996).

During storage, the preharvest treatments significantly $(\mathrm{P}<0.01)$ affected the TSS content of tomatoes. A pick increase in TSS was observed on day 12 for tomatoes subjected to NP, manure and control treatments whereas four days later in the preharvest $\mathrm{ComCat}^{\circledR}$, $\mathrm{ComCat}^{\circledR}+$ manure and $\mathrm{ComCat}^{\circledR}+\mathrm{NP}$ treatments. In addition, the TSS content started to decline on day 16 for the preharvest treatment of NP, manure and control tomatoes whereas the tomatoes subjected to preharvest $\mathrm{ComCat}^{\circledR}$, $\mathrm{ComCat}^{\circledR}+$ manure and $\mathrm{ComCat}^{\circledR}+\mathrm{NP}$ treatments showed a sharp decline on day 20 of the storage. The rapid decline in TSS content of tomato subjected to preharvest application of manure, NP fertilizer and control tomatoes might be due to higher rate of respiration associated with those tomatoes leading to faster ripening processes (Davies and Hobson, 1971). Disinfecting treatments significantly $(\mathrm{P}<0.05)$ affected the TSS content of tomatoes during storage period. The increase in TSS of tomatoes during storage is an indication of quality deterioration ( $\mathrm{Pal}$ and Roy, 1991; Wasker et al., 1999). Hot water treatment showed significantly $(\mathrm{P}<0.05)$ lower TSS during the storage periods except on day 16. Generally, tomatoes dipped in chlorinated and tap water contained more TSS during most of the storage periods. After 28 days of storage, increase in TSS content of tomato was shown by $3.98 \%$ and $2.68 \%$ in chlorinated and tap water dipped tomatoes than in hot water dipped tomatoes. The effect of storage conditions on the TSS of tomato fruit was $(\mathrm{P}<0.001)$ during the storage period. The TSS content of tomato fruit was maintained at lower levels in the evaporatively cooled storage than in the ambient storage. The slow changes in TSS of tomato fruit stored in the evaporative cooler compared to those stored at ambient conditions is in agreement with the finding of Pal and Roy (1991). Similarly, Kader (1985) reported increase in TSS content with the progression of storage and duration and storage temperature. Higher rates of increase in TSS of tomato samples stored at ambient temperature were reported to be caused by excessive moisture loss and the hydrolysis of carbohydrates to soluble sugars (Wasker et al., 1999). Changes in TSS occurred at substantially faster rates in tomatoes stored at room temperature than in tomatoes stored at cool storage conditions. The two-way interaction between preharvest and storage temperature showed highly significant $(p<0.05)$ effect on the TSS of tomato fruit during storage.

\section{3. $\mathrm{pH}$ Values}

The quality characteristic of tomato is influenced by the $\mathrm{pH}$ of fruit at harvest. There was an increase in the $\mathrm{pH}$ value of tomato fruit from 3.8 at harvest to 5.0 at the full ripe stage (Table 2 ). The $\mathrm{pH}$ of tomato is generally known to increase with an increasing ripeness (Mohamed et al., 1999).

Preharvest treatment significantly $(\mathrm{P}<0.01)$ affected the $\mathrm{pH}$ value of tomato fruit at harvest and throughout the storage period except on day 24. Immidiately after harvest, the $\mathrm{pH}$ of $\mathrm{ComCat}^{\circledR}$ treated tomato was significantly $(\mathrm{p}<0.01)$ lower except in tomatoes treated with ComCat ${ }^{\circledR}+$ manure. During the first four days of storage, significantly $(\mathrm{P}<0.01)$ higher $\mathrm{pH}$ value was observed in the untreated control tomato fruit showing difference in rate of metabolism. During the first 16 days, $\mathrm{ComCat}^{\circledR}, \mathrm{ComCat}^{\circledR}+\mathrm{NP}$ and $\mathrm{ComCat}^{\circledR}+$ manure treated tomatoes had significantly $(\mathrm{P}<0.01)$ lower $\mathrm{pH}$ values than the control tomatoes with the lowest $\mathrm{pH}$ value was being observed for tomatoes subjected to ComCat $^{\circledR}+$ manure treatment. The $\mathrm{pH}$ value of control tomato was lower than the $\mathrm{pH}$ values of tomatoes subjected to preharvest ComCat ${ }^{\circledR}$, manure, ComCat ${ }^{\circledR}+$ $\mathrm{NP}$ and $\mathrm{ComCat}^{\circledR}+$ manure treatment on day 20. On day 24 , only manure treatment tomatoes showed significantly $(\mathrm{P}<0.05)$ higher $\mathrm{pH}$ compared to control. Towards the end of the storage period, ComCat ${ }^{\circledR}$ treated tomato had shown significantly $(\mathrm{P}<0.01)$ lower $\mathrm{pH}$ when compared to the other treatments, except ComCat $^{\circledR}+$ manure. Similarly, ComCat ${ }^{\circledR}+$ manure treated tomatoes showed significantly $(\mathrm{P}<0.01)$ lower $\mathrm{pH}$ than manure and control tomatoes. In general, those tomatoes that received ComCat ${ }^{\circledR}$ either alone or in combination with the two forms of fertilizer showed lower $\mathrm{pH}$, especially in ComCat $^{\circledR}+$ manure treated tomatoes, during the 16 days of storage. However, these treatments showed higher $\mathrm{pH}$ value from 16 days onwards.

Disinfection treatments had brought significant $(\mathrm{P}<$ 0.01 ) effect on the $\mathrm{pH}$ values of tomato fruit from day 8 onwards. On day 8, tomato fruit dipped in chlorinated water had significantly $(\mathrm{P}<0.05)$ higher $\mathrm{pH}$ value than hot water dipped tomatoes. On day 12 , chlorinated water treatments significantly $(\mathrm{P}<0.01)$ increased the $\mathrm{pH}$ value when compared to tap water treatment. However, the effect of chlorinated and hot water treatment showed no variation on the $\mathrm{pH}$ value on days 12,16 and 24 . On day 
16, tomatoes subjected to both chlorinated and hot water treatments showed significantly $(\mathrm{P}<0.01)$ higher $\mathrm{pH}$ value than the $\mathrm{pH}$ values dipped in tap water. On day 20 , hot water treatment significantly $(\mathrm{P}<0.01)$ increased $\mathrm{pH}$ than both chlorinated and tap water treatments. At the end of storage period, fruit dipped in chlorinated water had significantly $(\mathrm{P}<0.01)$ higher $\mathrm{pH}$ value when compared to the $\mathrm{pH}$ values of tomatoes subjected to tap and hot water dipping treatments. Tomato fruit dipped in tap water showed significantly lower $\mathrm{pH}$ value during most part of the storage period $(\mathrm{P}<0.01)$.

Storage conditions significantly $(\mathrm{P}<0.001)$ affected the $\mathrm{pH}$ value of tomato fruit. The $\mathrm{pH}$ increased faster for tomatoes stored at ambient temperature than evaporative cooler. Lowering the storage temperature, to reduce respiration and delay senescence while high temperature storage resulted in faster ripening process. The increase in the $\mathrm{pH}$ values of tomato at ambient conditions with increase storage time was in agreement with the pervious findings (Mohammed et al., 1999). Others reported that the tendency of increasing $\mathrm{pH}$ value and reduced acidity is observed with longer storage time since the fruit with proceeding of the ripening process is going to diminish its predominant malic acid (Medlicoot et al. 1985). According to Mizrach et al. (1997) during postharvest ripening, carbohydrate and acid metabolism are closely connected. The two-way interaction between preharvest and storage conditions was significant $(\mathrm{P}<0.01)$ on the $\mathrm{pH}$ values of tomatoes during the 16 days of storage period. Similarly, the interaction between disinfection and storage temperature had significant $(\mathrm{p}<0.01)$ effect on $\mathrm{pH}$ value from 12 days onwards.

\subsection{Titiratable Acidity}

The predominant acid of ripe tomato fruit is citric and malic acid (Davies and Hobson 1971). In this study, titratable acidity (TA) decreased dramatically during ripening from the green mature to the full mature stage from around $1.36 \%$ to as low as $0.20 \%$ which agrees with the previous reports (Davies and Hobson, 1981; Salunkhe et al., 1991).

Preharvest treatments significantly $(\mathrm{P}<0.01)$ affected the TA of tomato fruit at harvest and during storage period (Table 2). At harvest, significantly $(p<0.01)$ higher TA content of tomato fruit was found in NP, manure and ComCat ${ }^{\circledR}$ treated tomato fruit compared to ComCat $^{\circledR}$ combined with the fertilizers and control tomatoes. The increase in TA of tomato treated with manure and NP fertilizer is in accordance with the result reported earlier (Hegde and Srinivas, 1990) that acidity increased with increasing fertilizer. ComCat ${ }^{\circledR}+\mathrm{NP}$ treated tomato also showed significantly $(p<0.01)$ higher TA than the controls. However, ComCat ${ }^{\circledR}+$ manure treated tomato had statistically comparable TA content with that of $\mathrm{ComCat}^{\circledR}+\mathrm{NP}$ and the control.

TA of tomato fruit grown using NP fertilizer was higher on day 8 and 12 of storage period when compared to the rest of the preharvest treatments applied. Hegde and Srinivas (1990) and Winsor and Adams (1976) also reported an increase in acidity of tomato with nitrogen application. The preharvest manure fertilized tomato fruit had higher TA when compared to ComCat ${ }^{\circledR}+$ manure, $\mathrm{ComCat}^{\circledR}+\mathrm{NP}$ and control tomato fruit during the first 8 days of storage. On day 16, the preharvest ComCat ${ }^{\circledR}$ and NP treated tomato fruit had significantly $(\mathrm{P}<0.01)$ higher TA content than the other treatments. Similarly, ComCat $^{\circledR}+$ manure and manure treated tomatoes had significantly $(\mathrm{P}<0.01)$ higher TA than $\mathrm{ComCat}^{\circledR}+\mathrm{NP}$ treated and control tomatoes. At the end of the storage periods, the preharvest ComCat ${ }^{\circledR}$ treated tomato fruit still had higher TA when compared to all of the other treatments.

The disinfection treatments had significant $(\mathrm{P}<0.05)$ effect on the level of TA only on day 12. The TA of tomato fruit dipped in chlorinated water was higher when compared to hot water dipped tomato fruit between 8 and 12 days of storage.

Storage temperature had highly significant $(\mathrm{P}<0.001)$ effect on the changes in TA of tomato fruit. During the 20 days of storage, the TA was found to be higher in tomato fruit stored using evaporatively cooled storage compared to those stored at ambient conditions. The relatively higher ambient temperature leads to higher rate of reduction in the TA as described in Koksal (1989). This could be associated with the higher rate of respiration using substrate for catabolic process for rapid ripening at higher temperature (Medicott et al., 1986). It is known that evaporatively cooled storage reduces respiratory activity, thereby delaying the ripening process and consequently increasing fruit shelf life (Seyoum, 2002; Seyoum and Woldetsadik, 2004). The two-way interaction between Preharvest treatments and storage environment had highly significant $(\mathrm{P}<0.01)$ effect on the changes in TA of tomato fruit. 
Table 1. Interaction effects of pre- and postharvest treatments on changes in the weight loss and total soluble solids content of tomato fruit over a storage period of 28 days.

\begin{tabular}{|c|c|c|c|c|c|c|c|c|c|c|c|c|c|c|c|}
\hline \multirow[t]{2}{*}{ Treatment } & \multicolumn{7}{|c|}{$\begin{array}{l}\text { Physiological weight loss }(\%) \\
\text { Storage period (day) }\end{array}$} & \multicolumn{8}{|c|}{$\begin{array}{l}\text { Total soluble solids ( }{ }^{\circ} \text { Brix) } \\
\text { Storage period (day) }\end{array}$} \\
\hline & 4 & 8 & 12 & 16 & 20 & 24 & 28 & 0 & 4 & 8 & 12 & 16 & 20 & 24 & 28 \\
\hline \multicolumn{16}{|l|}{ Preharvest (A) } \\
\hline $\mathrm{CC}$ & $2.66^{\mathrm{b}}$ & $4.75^{c}$ & $5.69 c$ & $10.06^{c}$ & $12.18^{\mathrm{d}}$ & $13.14^{\mathrm{d}}$ & $14.36^{c}$ & $4.87^{a}$ & $4.51^{b}$ & $4.88^{a}$ & $5.03^{\mathrm{ab}}$ & $5.07^{a}$ & $4.46^{\mathrm{ab}}$ & $4.59^{a}$ & $4.20^{\mathrm{a}}$ \\
\hline M & $3.55^{\mathrm{a}}$ & $6.05^{\mathrm{b}}$ & $6.98^{a}$ & $11.49^{\mathrm{a}}$ & $14.02^{\mathrm{b}}$ & $14.06^{\mathrm{a}}$ & $15.35^{\mathrm{b}}$ & $4.53^{\mathrm{ab}}$ & $4.58^{\mathrm{b}}$ & $4.92^{\mathrm{a}}$ & $5.04^{\mathrm{a}}$ & $4.87^{a}$ & $4.56^{\mathrm{a}}$ & $4.27^{\mathrm{b}}$ & $4.18^{a}$ \\
\hline NP & $3.59^{a}$ & $6.52^{\mathrm{a}}$ & $6.91^{\mathrm{a}}$ & $10.83^{\mathrm{b}}$ & $14.01^{b}$ & $13.49^{\mathrm{b}}$ & $16.31^{\mathrm{a}}$ & $4.33 \mathrm{bc}$ & $4.73^{a}$ & $4.94^{a}$ & $5.01^{\mathrm{ab}}$ & $4.57^{b}$ & $4.34^{\mathrm{bc}}$ & $4.37 \mathrm{ab}$ & $4.02^{\mathrm{a}}$ \\
\hline $\mathrm{CC}+\mathrm{M}$ & $2.69^{\mathrm{b}}$ & $4.89 \mathrm{c}$ & $6.33^{\mathrm{b}}$ & $10.82^{\mathrm{b}}$ & $13.16^{\mathrm{c}}$ & $13.26^{c}$ & $15.52^{\mathrm{b}}$ & $4.33^{\mathrm{bc}}$ & $4.54^{\mathrm{b}}$ & $4.81^{\mathrm{a}}$ & $4.80^{c}$ & $4.88^{a}$ & $4.26^{c}$ & $4.12^{\mathrm{b}}$ & $4.11^{\mathrm{a}}$ \\
\hline $\mathrm{CC}+\mathrm{NP}$ & $3.56^{\mathrm{a}}$ & $6.06^{\mathrm{b}}$ & $6.30^{\mathrm{b}}$ & $10.82^{\mathrm{b}}$ & $13.15^{\mathrm{c}}$ & $13.11^{\mathrm{d}}$ & $15.10^{\mathrm{b}}$ & $4.07^{c}$ & $4.50^{\mathrm{b}}$ & $4.86^{a}$ & $4.85^{\mathrm{bc}}$ & $4.84^{a}$ & $4.28 \mathrm{bc}$ & $4.19^{\mathrm{b}}$ & $4.13^{a}$ \\
\hline Control & $3.56^{\mathrm{a}}$ & $6.51^{\mathrm{a}}$ & $6.98^{a}$ & $11.54^{\mathrm{a}}$ & $14.40^{\mathrm{a}}$ & $14.04^{\mathrm{a}}$ & $16.45^{\mathrm{a}}$ & $4.67 \mathrm{ab}$ & $4.58^{\mathrm{b}}$ & $4.96^{\mathrm{a}}$ & 4.99ab & $4.83^{\mathrm{a}}$ & $4.32^{\mathrm{bc}}$ & $4.19^{\mathrm{b}}$ & $4.04^{\mathrm{a}}$ \\
\hline LSD & $* *$ & ** & ** & $* *$ & $* *$ & ** & $* *$ & $* *$ & $*$ & $*$ & $*$ & $* *$ & $* *$ & $*$ & ns \\
\hline $\mathrm{SE} \pm$ & 0.05 & 0.06 & 0.05 & 0.02 & 0.02 & 0.03 & 0.15 & 0.06 & 0.06 & 0.07 & 0.06 & 0.06 & 0.06 & 0.10 & 0.08 \\
\hline \multicolumn{16}{|l|}{ Disinfection (B) } \\
\hline $\mathrm{NaOCL}$ & $3.27^{a}$ & $5.79^{a}$ & $6.53^{\mathrm{a}}$ & $11.08^{\mathrm{a}}$ & $13.76^{\mathrm{a}}$ & $13.65^{\mathrm{a}}$ & $15.71^{\mathrm{a}}$ & $4.34^{\mathrm{a}}$ & $4.54^{b}$ & $4.83^{\mathrm{b}}$ & $5.09^{a}$ & $4.99 a$ & $4.49^{a}$ & $4.36^{\mathrm{a}}$ & $4.19^{a}$ \\
\hline $\mathrm{H}_{2} \mathrm{O}, 52^{\circ} \mathrm{C}$ & $3.26^{\mathrm{a}}$ & $5.80^{\mathrm{a}}$ & $6.53^{a}$ & $10.84^{\mathrm{b}}$ & $13.33^{\mathrm{b}}$ & $13.41^{b}$ & $15.32^{\mathrm{bc}}$ & $4.46^{a}$ & $4.51^{\mathrm{b}}$ & $4.81^{\mathrm{b}}$ & $4.80^{\mathrm{b}}$ & $4.65^{a}$ & $4.21^{b}$ & $4.11^{\mathrm{b}}$ & $4.02^{\mathrm{b}}$ \\
\hline $\mathrm{H}_{2} \mathrm{O}, 24.2^{\circ} \mathrm{C}$ & $3.27^{\mathrm{a}}$ & $5.80^{\mathrm{a}}$ & $6.53^{\mathrm{a}}$ & $10.86^{\mathrm{b}}$ & $13.35^{\mathrm{b}}$ & $13.49^{\mathrm{b}}$ & $15.51^{\mathrm{b}}$ & $4.44^{\mathrm{a}}$ & $4.67^{a}$ & $5.04^{\mathrm{a}}$ & $4.98^{a}$ & $4.89^{a}$ & $4.40^{\mathrm{a}}$ & $4.39^{\mathrm{a}}$ & $4.13^{\mathrm{ab}}$ \\
\hline LSD & ns & ns & ns & $* *$ & $* *$ & $* *$ & $* *$ & ns & $*$ & $*$ & $* *$ & ns & $* *$ & $*$ & $*$ \\
\hline $\mathrm{SE} \pm$ & 0.04 & 0.04 & 0.04 & 0.01 & 0.01 & 0.02 & 0.11 & 0.06 & 0.04 & 0.05 & 0.04 & 0.04 & 0.04 & 0.07 & 0.05 \\
\hline \multicolumn{16}{|c|}{ Storage condition $(\mathrm{C})$} \\
\hline EC & $2.20^{\mathrm{b}}$ & $3.88^{b}$ & $4.92^{\mathrm{b}}$ & $7.40^{\mathrm{b}}$ & $10.73^{\mathrm{b}}$ & - & - & - & $4.26^{\mathrm{b}}$ & $4.56^{\mathrm{b}}$ & $4.78^{b}$ & $4.49 \mathrm{~b}$ & $4.58^{a}$ & - & - \\
\hline $\mathrm{AM}$ & $4.34^{\mathrm{a}}$ & $7.69^{a}$ & $8.15^{\mathrm{a}}$ & $14.45^{\mathrm{a}}$ & $16.24^{\mathrm{a}}$ & - & - & - & $4.88^{\mathrm{a}}$ & $5.23^{\mathrm{a}}$ & $5.14^{\mathrm{a}}$ & $5.19^{a}$ & $4.15^{\mathrm{b}}$ & - & - \\
\hline LSD & $* * *$ & $* * *$ & $* * *$ & $* * *$ & $* * *$ & - & - & & $* * *$ & $* * *$ & $* * *$ & $* * *$ & $* * *$ & - & - \\
\hline $\mathrm{SE} \pm$ & 0.03 & 0.034 & 0.03 & 0.01 & 0.01 & - & - & & 0.04 & 0.04 & 0.03 & 0.03 & 0.03 & - & - \\
\hline \multicolumn{16}{|l|}{ Significance } \\
\hline $\mathrm{AXB}$ & ns & ns & ns & $*$ & $* *$ & $* *$ & ns & ns & ns & ns & ns & ns & ns & ns & ns \\
\hline $\mathrm{AXC}$ & $* * *$ & $* * *$ & $* * *$ & $* * *$ & *** & - & - & - & $* * *$ & $* * *$ & $*$ & ** & $*$ & - & - \\
\hline BXC & ns & Ns & ns & ns & $* *$ & - & - & - & ns & ns & ns & ns & ns & - & - \\
\hline AXBXC & $\mathrm{ns}$ & Ns & ns & $* * *$ & $* *$ & - & - & - & ns & ns & ns & ns & ns & - & - \\
\hline
\end{tabular}

Weight loss calculated as percentage of initial weight (0 day) and the weight loss and TSS data for day 24 and 28 are mean values for evaporatively cooled storage. Means within the same column followed by a common letter are not significantly different at $P<0.01$ by DMRT where NS, *, **, *** indicate nonsignificant or significant difference at $p<0.05,0.01$ or 0.001 ,.respectively; $A$

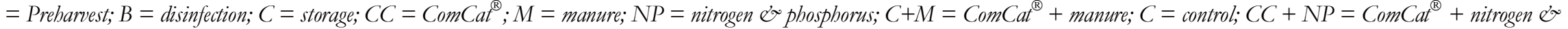
phosphorus; $E C=$ evaporative cooling; $A M=$ ambient storage 
Table 2. Interaction effects of pre- and postharvest treatments on changes in ihe $\mathrm{pH}$ and titratable acidity of tomato fruit over a storage period of 28 days.

\begin{tabular}{|c|c|c|c|c|c|c|c|c|c|c|c|c|c|c|c|c|}
\hline \multirow[t]{2}{*}{ Treatment } & \multicolumn{9}{|c|}{$\begin{array}{l}\mathrm{pH} \text { values } \\
\text { Storage period (day) }\end{array}$} & \multicolumn{7}{|c|}{$\begin{array}{l}\text { Total titratable acidity }(\%) \\
\text { Storage period (day) }\end{array}$} \\
\hline & 0 & 4 & 8 & 12 & 16 & 20 & 24 & 28 & 0 & 4 & 8 & 12 & 16 & 20 & 24 & 28 \\
\hline \multicolumn{17}{|l|}{ Preharvest (A) } \\
\hline $\mathrm{CC}$ & $3.84^{c}$ & $4.12^{\mathrm{b}}$ & $4.27 \mathrm{~b}$ & $4.65^{b}$ & $4.73^{b}$ & $4.80^{\mathrm{a}}$ & $4.85^{\mathrm{ab}}$ & $4.75^{c}$ & $1.25^{\mathrm{a}}$ & $0.61^{\mathrm{b}}$ & $0.56^{\mathrm{b}}$ & $0.53^{\mathrm{b}}$ & $0.459^{a}$ & $0.449^{a}$ & $0.44^{a}$ & $0.37^{a}$ \\
\hline $\mathrm{M}$ & $3.98^{\mathrm{b}}$ & $4.17^{\mathrm{b}}$ & $4.32^{\mathrm{ab}}$ & $4.63^{\mathrm{b}}$ & $4.71^{b}$ & $4.76^{\mathrm{a}}$ & $4.89^{\mathrm{a}}$ & $4.91^{\mathrm{a}}$ & $1.209^{\mathrm{a}}$ & $0.79^{\mathrm{a}}$ & $0.55^{\mathrm{b}}$ & $0.47^{c}$ & $0.378^{\mathrm{b}}$ & $0.36^{\mathrm{b}}$ & $0.36^{\mathrm{b}}$ & $0.24^{b}$ \\
\hline $\mathrm{NP}$ & $4.02^{\mathrm{b}}$ & $4.18^{\mathrm{b}}$ & $4.35^{\mathrm{ab}}$ & $4.58^{\mathrm{b}}$ & $4.66^{\mathrm{b}}$ & $4.74^{\mathrm{ab}}$ & $4.77^{b}$ & $4.88^{\mathrm{ab}}$ & $1.376^{\mathrm{a}}$ & $0.585^{b c}$ & $0.858^{\mathrm{a}}$ & $0.57^{\mathrm{a}}$ & $0.468^{\mathrm{a}}$ & $0.46^{\mathrm{a}}$ & $0.29^{c}$ & $0.28^{\mathrm{b}}$ \\
\hline $\mathrm{CC}+\mathrm{M}$ & $3.93 \mathrm{bc}$ & $3.84^{\mathrm{c}}$ & $4.09 c$ & $4.22^{c}$ & $4.50^{c}$ & $4.80^{\mathrm{a}}$ & $4.82^{\mathrm{ab}}$ & $4.78^{b c}$ & $0.45^{\mathrm{bc}}$ & $0.53^{\mathrm{d}}$ & $0.427 \mathrm{~d}$ & $0.41^{\mathrm{d}}$ & $0.40^{\mathrm{b}}$ & $0.31^{c}$ & $0.32^{c}$ & $0.27 \mathrm{~b}$ \\
\hline $\mathrm{CC}+\mathrm{NP}$ & $4.04^{\mathrm{b}}$ & $4.15^{\mathrm{b}}$ & $4.29 \mathrm{~b}$ & $4.52^{\mathrm{b}}$ & $4.71^{b}$ & $4.76^{a}$ & $4.75^{\mathrm{b}}$ & $4.86^{\mathrm{ab}}$ & $0.59^{\mathrm{b}}$ & $0.56^{\mathrm{cd}}$ & $0.42^{\mathrm{d}}$ & $0.45^{c}$ & $0.33^{c}$ & $0.29 \mathrm{~cd}$ & $0.28^{c}$ & $0.25^{b}$ \\
\hline Control & $4.21^{\mathrm{a}}$ & $4.64^{a}$ & $4.44^{a}$ & $4.74^{a}$ & $4.81^{\mathrm{a}}$ & $4.67 \mathrm{~b}$ & $4.76^{\mathrm{b}}$ & $4.90^{\mathrm{a}}$ & $0.37 \mathrm{c}$ & $0.45^{\mathrm{e}}$ & $0.50^{c}$ & $0.458^{c}$ & $0.32^{c}$ & $0.28^{\mathrm{d}}$ & $0.23^{\mathrm{d}}$ & $0.23^{b}$ \\
\hline LSD & $* *$ & $* *$ & $* *$ & $* *$ & $* *$ & $*$ & $\mathrm{Ns}$ & $*$ & $* *$ & $* *$ & $* *$ & $* *$ & $* *$ & $* *$ & $* *$ & $* *$ \\
\hline $\mathrm{SE} \pm$ & 0.01 & 0.04 & 0.03 & 0.02 & 0.02 & 0.03 & 0.04 & 0.03 & 0.01 & 0.01 & 0.01 & 0.01 & 0.01 & 0.01 & 0.01 & 0.01 \\
\hline \multicolumn{17}{|l|}{ Disinfection (B) } \\
\hline $\mathrm{NaOCL}$ & $4.00^{\mathrm{a}}$ & $4.23^{\mathrm{a}}$ & $4.38^{\mathrm{a}}$ & $4.61^{\mathrm{a}}$ & $4.74^{\mathrm{a}}$ & $4.75^{b}$ & $4.79 \mathrm{a}$ & $4.89^{\mathrm{b}}$ & $0.87 \mathrm{a}$ & $0.59^{a}$ & $0.57^{\mathrm{a}}$ & $0.49^{a}$ & $0.39^{\mathrm{a}}$ & $0.36^{\mathrm{a}}$ & $0.33^{\mathrm{a}}$ & $0.29^{a}$ \\
\hline $\mathrm{H}_{2} \mathrm{O}, 52^{\circ} \mathrm{C}$ & $3.99^{a}$ & $4.16^{\mathrm{a}}$ & $4.31^{\mathrm{b}}$ & $4.57 \mathrm{ab}$ & $4.69^{\mathrm{a}}$ & $4.81^{\mathrm{a}}$ & $4.84^{a}$ & $4.83^{\mathrm{a}}$ & $0.85^{\mathrm{a}}$ & $0.59^{\mathrm{a}}$ & $0.54^{\mathrm{b}}$ & $0.47 \mathrm{~b}$ & $0.39^{\mathrm{a}}$ & $0.36^{\mathrm{a}}$ & $0.31^{\mathrm{a}}$ & $0.27 \mathrm{a}$ \\
\hline $\mathrm{H}_{2} \mathrm{O}, 24.2^{\circ} \mathrm{C}$ & $4.00^{\mathrm{a}}$ & $4.16^{\mathrm{a}}$ & $4.41^{\mathrm{ab}}$ & $4.53^{\mathrm{b}}$ & $4.63^{\mathrm{b}}$ & $4.71^{b}$ & $4.79^{\mathrm{a}}$ & $4.83^{\mathrm{b}}$ & $0.88^{\mathrm{a}}$ & $0.59^{\mathrm{a}}$ & $0.56^{\mathrm{ab}}$ & $0.48^{\mathrm{ab}}$ & $0.40^{\mathrm{a}}$ & $0.36^{\mathrm{a}}$ & $0.32^{\mathrm{a}}$ & $0.27^{\mathrm{a}}$ \\
\hline LSD & NS & NS & $*$ & $* *$ & $* *$ & $* *$ & NS & $*$ & Ns & Ns & Ns & $*$ & Ns & Ns & Ns & Ns \\
\hline $\mathrm{SE} \pm$ & 0.01 & 0.03 & 0.02 & 0.04 & 0.01 & 0.02 & 0.03 & 0.02 & 0.03 & 0.01 & 0.01 & 0.01 & 0.01 & 0.01 & 0.01 & 0.01 \\
\hline \multicolumn{17}{|l|}{ Storage $(\mathrm{C})$} \\
\hline EC & - & $4.10^{\mathrm{b}}$ & $4.24^{\mathrm{b}}$ & $4.48^{\mathrm{b}}$ & $4.60^{\mathrm{b}}$ & $4.72^{\mathrm{b}}$ & - & - & - & $0.68^{a}$ & $0.64^{\mathrm{a}}$ & $0.55^{\mathrm{b}}$ & $0.47^{\mathrm{a}}$ & $0.42^{\mathrm{b}}$ & - & - \\
\hline $\mathrm{AM}$ & - & $4.26^{a}$ & $4.39^{\mathrm{a}}$ & $4.66^{\mathrm{a}}$ & $4.77^{a}$ & $4.79^{a}$ & - & - & - & $0.50^{\mathrm{b}}$ & $0.47^{b}$ & $0.41^{\mathrm{a}}$ & $0.32^{\mathrm{b}}$ & $0.29^{\mathrm{a}}$ & - & - \\
\hline LSD & & $* * *$ & $* * *$ & $* * *$ & $* * *$ & $* * *$ & & & & $* * *$ & $* * *$ & $* * *$ & $* * *$ & $* * *$ & - & - \\
\hline $\mathrm{SE} \pm$ & & 0.03 & 0.02 & 0.01 & 0.01 & 0.02 & & & - & 0.01 & 0.01 & 0.004 & 0.004 & 0.004 & - & - \\
\hline \multicolumn{17}{|l|}{ Significance } \\
\hline $\mathrm{AXB}$ & ns & ns & ns & ns & ns & Ns & ns & ns & - & ns & ns & ns & ns & ns & ns & ns \\
\hline AXC & - & $*$ & $*$ & $* * *$ & $* * *$ & $\mathrm{Ns}$ & - & - & - & $* * *$ & $* * *$ & $* * *$ & $* * *$ & $* * *$ & - & - \\
\hline $\mathrm{BXC}$ & - & ns & ns & $* *$ & $* * *$ & $*$ & - & - & - & ns & ns & ns & ns & ns & - & - \\
\hline AXBXC & - & ns & ns & ns & ns & Ns & - & - & - & ns & ns & ns & ns & ns & - & - \\
\hline
\end{tabular}

$\mathrm{pH}$ and titratable acidity data for 20 days of storage and the data of day 24 and 28 are mean values for EC only. Means within the same column followed by a common letter are not significantly different at $p<0.01$ by DMRT where ns, *,**,** indicate nonsignificant or significant difference at $P<0.05,0.01$ or 0.001, respectively. $A=P$ Preharvest; $B=$ disinfection; $C=$ storage; $C C=$

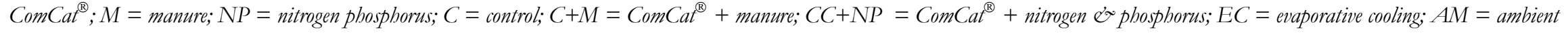
storage 


\subsection{Ascorbic Acid}

Several investigators reported an increase in ascorbic acid content with ripening with either a continuing rise or a slight fall (Dalal et al., 1965) during the final stages of ripening. Watada et al. (1976) also reported AA content of mature green tomato fruit to be essentially the same as in fully ripened ones. In the present study the increase in AA content, followed by a fall during the full ripening stage, was observed (Table 3).

At harvest, the application of manure had a positive effect on the accumulation of AA content in tomatoes. Raupp (1996) draws attention to the positive effect of manure on the content of AA in vegetables. Cacek and Lagner (1986) also confirmed the positive effect of organic fertilizer on the AA content of vegetable. ComCat $^{\circledR}+\mathrm{NP}$ treatment significantly $(\mathrm{p}<0.01)$ lowered AA content of tomato fruit compared to the control. The lower AA content in the preharvest NP and ComCat $^{\circledR}+$ NP treatments could be due to the effect of $\mathrm{N}$ fertilization. Likewise, Augustin (1975) and Lisiewska and Kmiecik (1996) reported a decrease in AA content of fruit and vegetables with increasing amounts of nitrogen fertilizer. One possible explanation for the lower AA content in the preharvest NP and ComCat $^{\circledR}+\mathrm{NP}$ treatments could be due to the vegetative growth that impairs the reproductive development and this may probably decreased the sink strength, as a result decreases AA.

The preharvest treatment had also shown significant $(\mathrm{P}$ $<0.01)$ effect on the AA content of tomato fruit during the storage period. The preharvest manure fertilized tomato fruit maintained higher AA contents up to 12 days of storage compared to the other preharvest treatments. Towards the end of the storage period, ComCat $^{\circledR}$ maintained higher amount of $\mathrm{AA}$ than the other treatments. The preharvest ComCat ${ }^{\circledR}+$ manure and ComCat $^{\circledR}+\mathrm{NP}$ treated tomatoes also had significantly higher AA content during the first 12 days of storage compared to control tomatoes. However, ComCat ${ }^{\circledR}+$ manure had significantly higher AA content than ComCat $^{\circledR}+\mathrm{NP}$ treated tomatoes. Those tomatoes subjected to preharvest ComCat ${ }^{\circledR}$ and manure treatments had longer and wider leaves during the preharvest condition and this might have contributed to an increase in AA since light plays an important role in AA accumulation in tomato fruit (Davies and Hobson, 1971).

After 20 days of storage at ambient conditions, the preharvest manure and ComCat ${ }^{\circledR}$ treated tomato fruit had higher AA, followed by ComCat ${ }^{\circledR}+\mathrm{NP}$ treated tomato fruit while the preharvest NP and ComCat ${ }^{\circledR}+\mathrm{NP}$ treated tomato fruit contained higher AA when compared to the control tomatoes. Davies and Hobson (1971) reported that additional soil nitrogen application decreased the ascorbic acid. It appears from this that the growth of foliage in NP and ComCat ${ }^{\circledR}+\mathrm{NP}$ treated tomatoes might have affected the AA. It is probable that the individual fruit were shaded to some extent in NP and ComCat ${ }^{\circledR}+$ NP treated plots. Thus, exposure of the fruit to light may have been a factor since light plays an important role in ascorbic acid accumulation in tomato fruit (Davies and Hobson, 1971).

Disinfecting treatments showed significant $(\mathrm{P}<0.05)$ effect on the AA content of tomato except on day 0 and 28. The AA content of tomato fruit dipped in hot water were higher than the AA content of chlorine dipped and control tomato fruit in most storage periods. McDonald et al. (1979) reported that some heat treatments could delay or inhibit ripening in certain tomato varieties. This is attributed to the fact that blanching reduced the metabolic rate and hence limits the chemical and biochemical changes during storage due to inactivation of enzymes.

AA content of tomato fruit increased with ripening during 20 days at cooled storage while it rapidly increased during the first 8 days of ripening at ambient conditions and showed a decline after full ripening. This trend was in agreement with the previous data that AA content increased with ripeness (Mohammed et al., 1999; Seyoum, 2002). After 12 days, significantly $(\mathrm{P}<0.01)$ higher $\mathrm{AA}$ content of tomatoes stored at evaporatively cooled storage condition was observed than storage at ambient conditions. High temperature is known to increase enzymatic catalysis and lead to biochemical breakdown of compounds in fruit and vegetables (Yeshida et al., 1994). At relatively low storage temperature slow ripening of tomatoes would be associated with slow chemical and biochemical processes.

The two-way interaction between disinfection and storage environment showed nonsignificant $(\mathrm{P}>0.01)$ variation expect on days 12 and 16 . The interaction between the preharvest treatments and storage environment had highly significant $(\mathrm{P}<0.01)$ effect on AA content of tomatoes. 
Table 3. Effect of different preharvest, disinfection and storage treatments on ascorbic acid content and percent marketability of tomatoes over a storage period of 28 days.

\begin{tabular}{|c|c|c|c|c|c|c|c|c|c|c|c|c|c|c|}
\hline \multirow[t]{2}{*}{ Treatment } & \multicolumn{8}{|c|}{$\begin{array}{l}\text { Ascorbic Acid, mg 100g-1 } \\
\text { Storage period (day) }\end{array}$} & \multicolumn{6}{|c|}{$\begin{array}{l}\text { Marketability ( } \%) \\
\text { Storage period (day) }\end{array}$} \\
\hline & 0 & 4 & 8 & 12 & 16 & 20 & 24 & 28 & 8 & 12 & 16 & 20 & 24 & 28 \\
\hline \multicolumn{15}{|l|}{ Preharvest (A) } \\
\hline $\mathrm{CC}$ & $11.72^{\mathrm{bc}}$ & $14.17 \mathrm{~b}$ & $15.04^{c}$ & $15.85^{\mathrm{b}}$ & $15.78^{a}$ & $14.41^{\mathrm{a}}$ & $14.86^{\mathrm{a}}$ & $13.53^{\mathrm{a}}$ & $92.77^{a}$ & $74.60^{a}$ & $64.68^{a}$ & $50.62^{\mathrm{a}}$ & $40.80^{a}$ & $28.64^{a}$ \\
\hline $\mathrm{M}$ & $14.92^{\mathrm{a}}$ & $16.02^{\mathrm{a}}$ & $19.75^{a}$ & $16.12^{\mathrm{a}}$ & $15.86^{\mathrm{a}}$ & $14.53^{a}$ & $13.12^{\mathrm{b}}$ & $11.56^{\mathrm{b}}$ & $90.30^{a}$ & $76.14^{a}$ & $55.06^{\mathrm{b}}$ & $33.54 \mathrm{bc}$ & $20.48^{c}$ & $18.84^{\mathrm{bc}}$ \\
\hline NP & $12.97^{b}$ & $13.82^{\mathrm{c}}$ & $15.10^{c}$ & $12.98^{\mathrm{e}}$ & $12.17^{c}$ & $12.12^{\mathrm{c}}$ & $11.94^{\mathrm{b}}$ & $11.50^{\mathrm{b}}$ & $86.49^{\mathrm{b}}$ & $69.81^{b}$ & $55.15^{\mathrm{b}}$ & $36.33^{\mathrm{b}}$ & $19.64^{c}$ & $17.12^{\mathrm{c}}$ \\
\hline $\mathrm{CC}+\mathrm{M}$ & $12.36^{\mathrm{b}}$ & $14.22^{\mathrm{b}}$ & $16.546^{\mathrm{b}}$ & $14.35^{c}$ & $12.60^{\mathrm{b}}$ & $12.33^{\mathrm{b}}$ & $12.54^{\mathrm{b}}$ & $11.21^{\mathrm{b}}$ & $91.67^{a}$ & $69.72^{\mathrm{b}}$ & $50.64^{\mathrm{b}}$ & $31.19^{c}$ & $26.83^{\mathrm{b}}$ & $20.78^{b}$ \\
\hline $\mathrm{CC}+\mathrm{NP}$ & $10.88^{\mathrm{c}}$ & $12.56^{\mathrm{d}}$ & $14.68^{\mathrm{d}}$ & $14.02^{\mathrm{d}}$ & $12.03^{c}$ & $11.99 \mathrm{c}$ & $12.19^{b}$ & $11.64^{b}$ & $86.16^{\mathrm{b}}$ & $67.48^{\mathrm{b}}$ & $53.67^{b}$ & $26.65^{\mathrm{d}}$ & $18.55^{\mathrm{c}}$ & $15.22^{c}$ \\
\hline Control & $13.00^{\mathrm{b}}$ & $11.89 \mathrm{e}$ & $12.966^{\mathrm{e}}$ & $12.07^{\mathrm{f}}$ & $11.76^{\mathrm{d}}$ & $11.62^{\mathrm{d}}$ & $12.39^{\mathrm{b}}$ & $11.40^{\mathrm{b}}$ & $86.47 \mathrm{~b}$ & $69.72^{\mathrm{b}}$ & $44.96^{c}$ & $26.74^{\mathrm{d}}$ & $19.35^{c}$ & $16.19 \mathrm{c}$ \\
\hline LSD & $* *$ & $* *$ & $* *$ & $* *$ & $* *$ & ** & $* *$ & $* *$ & $* *$ & $* *$ & ** & ** & $* *$ & *** \\
\hline $\mathrm{SE} \pm$ & 0.561 & 0.07 & 0.05 & 0.05 & 0.051 & 0.040 & 0.38 & 0.31 & 0.68 & 1.01 & 1.198 & 1.05 & 0.84 & 0.95 \\
\hline \multicolumn{15}{|l|}{ Disinfection (B) } \\
\hline $\mathrm{NaOCL}$ & $12.64^{\mathrm{a}}$ & $13.70^{\mathrm{b}}$ & $15.57^{b}$ & $14.17 \mathrm{~b}$ & $13.44^{\mathrm{a}}$ & $12.75^{\mathrm{b}}$ & $13.13^{a}$ & $11.91^{\mathrm{a}}$ & $88.88^{a}$ & $72.81^{b}$ & $56.70^{\mathrm{a}}$ & $39.32^{a}$ & $29.27^{a}$ & $24.05^{\mathrm{a}}$ \\
\hline $\mathrm{H}_{2} \mathrm{O}, 52^{\circ} \mathrm{C}$ & $12.63^{a}$ & $13.89^{a}$ & $15.88^{a}$ & $14.23^{\mathrm{ab}}$ & $13.26^{\mathrm{b}}$ & $13.05^{\mathrm{a}}$ & $13.18^{\mathrm{a}}$ & $11.90^{\mathrm{a}}$ & $89.09^{a}$ & $75.80^{a}$ & $59.56^{a}$ & $35.29 \mathrm{~b}$ & $23.89^{\mathrm{b}}$ & $19.51^{\mathrm{b}}$ \\
\hline $\mathrm{H}_{2} \mathrm{O}, 24.2^{\circ} \mathrm{C}$ & $12.63^{\mathrm{a}}$ & $13.74^{\mathrm{ab}}$ & $15.59^{\mathrm{b}}$ & $14.29^{\mathrm{a}}$ & $13.40^{\mathrm{a}}$ & $12.69^{\mathrm{b}}$ & $12.22^{\mathrm{b}}$ & $11.61^{\mathrm{a}}$ & $88.96^{\mathrm{a}}$ & $65.12^{c}$ & $45.82^{\mathrm{b}}$ & $27.92^{c}$ & $19.66^{c}$ & $14.84^{c}$ \\
\hline LSD & ns & $*$ & $* *$ & $*$ & $* *$ & $* *$ & $* *$ & $\mathrm{Ns}$ & $\mathrm{Ns}$ & $* *$ & $* *$ & $* *$ & $* *$ & $* *$ \\
\hline $\mathrm{SE} \pm$ & 0.06 & 0.054 & 0.04 & 0.04 & 0.036 & 0.028 & 0.27 & 0.22 & 0.48 & 0.714 & 0.847 & 0.74 & 0.60 & 0.67 \\
\hline \multicolumn{15}{|c|}{ Storage conditions $(\mathrm{C})$} \\
\hline EC & - & $13.13^{\mathrm{b}}$ & $13.87^{\mathrm{b}}$ & $14.62^{\mathrm{a}}$ & $15.34^{\mathrm{a}}$ & $15.90^{\mathrm{a}}$ & - & - & $100.00^{\mathrm{a}}$ & $82.75^{\mathrm{a}}$ & $65.15^{\mathrm{a}}$ & $45.09^{\mathrm{a}}$ & - & - \\
\hline $\mathrm{AM}$ & - & $14.43^{\mathrm{a}}$ & $17.50^{\mathrm{a}}$ & $13.85^{\mathrm{b}}$ & $11.40^{\mathrm{b}}$ & $9.77^{b}$ & - & - & $77.95^{\mathrm{b}}$ & $59.74^{\mathrm{b}}$ & $42.90^{\mathrm{b}}$ & $23.27^{\mathrm{b}}$ & - & - \\
\hline LSD & & $* *$ & $* *$ & $* *$ & $* *$ & $* *$ & & & $* *$ & $* *$ & $* *$ & $* *$ & - & - \\
\hline $\mathrm{SE} \pm$ & - & 0.044 & 0.03 & 0.031 & 0.03 & 0.023 & - & - & 0.39 & 0.58 & 0.69 & 0.60 & - & - \\
\hline \multicolumn{15}{|l|}{ Significance } \\
\hline $\mathrm{AXB}$ & ns & ns & ns & ns & ns & $* *$ & * & ns & ns & ns & ns & ns & $*$ & ns \\
\hline AXC & - & $* * *$ & $* * *$ & $* * *$ & $* * *$ & $* * *$ & - & - & $* * *$ & $*$ & ns & $* * *$ & - & - \\
\hline $\mathrm{BXC}$ & - & ns & ns & $* * *$ & $* *$ & Ns & - & - & ns & $* * *$ & $* * *$ & ns & - & - \\
\hline AXBXC & - & ns & ns & ns & ns & $* *$ & - & - & ns & ns & ns & ns & - & - \\
\hline
\end{tabular}




\subsection{Percentage Marketability}

On day 8, the preharvest $\mathrm{ComCat}^{\circledR}$, manure and ComCat $^{\circledR}+$ manure treatments significantly $(\mathrm{P}<0.01)$ increased percent marketability of tomato when compared to the other treatments. On day 12 ComCat $^{\circledR}$ and manure treatments kept on significantly $(\mathrm{P}<0.01)$ higher percentage marketability of fruit over the others treatments. From day 16 onwards, the preharvest ComCat $^{\circledR}$ treatment significantly $(\mathrm{P}<0.01)$ increased the percent marketability when compared to the rest of the preharvest treatments. On day 16, ComCat ${ }^{\circledR}+$ manure, ComCat $^{\circledR}+\mathrm{NP}$, manure and NP treatments had higher percent marketable fruit than control tomatoes.

On day 20, lower percent marketability of tomato fruit was observed in the preharvest treatments of ComCat ${ }^{\circledR}+$ NP and control tomatoes. During the last two storage interval days, ComCat $\left.{ }^{(}\right)$and control treatments showed significant $(\mathrm{P}<0.01)$ variations in percent marketable tomatoes where on day 28 the preharvest ComCat ${ }^{\circledR}$, ComCat $^{\circledR}+$ manure, manure and NP treatment had $43.4 \%, 22.0 \%, 14.0 \%$, and $5.4 \%$, respectively, more marketable fruit over the control treatment. However, ComCat $^{\circledR}+\mathrm{NP}$ treated tomatoes showed reduction of percent marketability by $6.3 \%$ when compared to the control. The preharvest ComCat ${ }^{\circledR}+$ manure and manure treated tomatoes also had improved percent marketable tomatoes.

Disinfecting did not show significant effect on the percentage marketability of tomato fruit for the first 8 days of the storage periods but there after it showed significant $(\mathrm{P}<0.01)$ effect until the end of the storage period. On day 12, hot water dipping treatment improved percent marketability by $3.9 \%$ over chlorinated water dipping treatment and by $14 \%$ over the tap water dipping control treatment.

On day 16, no difference was observed due to both chlorinated and hot water dipping treatment on percent marketability but both treatments significantly $(\mathrm{P}<0.01)$ improved the percent marketability when compared to tap water dipping treatment. During the last three sampling intervals, chlorinated water dipping treatment significantly improved percent marketability than hot and tap water dipping treatments. However, hot water dipping treatment resulted in a good and attractive colored fruit while chlorine dipping left a taint on the surface of some samples of tomato during those days of storage. The higher percent marketability in chlorinated water treatment could be due to the action of chlorine as disinfecting agent and control of microorganisms, which is responsible for decay. Water washed tomato fruit (control) had lower percentage of marketable tomato fruit throughout the storage periods when compared to chlorine and hot water treatments.

The percentage marketability of tomato fruit stored in the evaporative cooling chamber was higher than those stored at ambient conditions. In this experiment, mature green tomato fruit could be stored for a period of 32 days in evaporatively cooled storage against 16 days under ambient temperature conditions. Tomato fruit stored at cool storage remained fresh, firm, shiny and had attractive color for a reasonable period of time. The termination of shelf life of tomatoes, on day 20, at ambient conditions was determined by shriveling, which produced plainly visible wrinkling and discoloration, making the fruit unacceptable for market. The percentage marketable fruit were lower $(\mathrm{P}<0.01)$ by $48 \%$ for tomatoes stored at AM than those stored at evaporatively cooled storage at the end of the storage day. In addition, over-ripening and soft rot were the most serious problems associated with tomatoes stored at ambient temperature and humidity. Similar observations were reported by Pal and Roy (1991) and Seyoum (2002). The interaction effect between preharvest and storage condition was highly significantly $(\mathrm{P}<0.01)$ except on day 16. Similarly, the interaction between disinfecting and storage treatment had shown significant effect on percent marketable tomato fruit on day 12 and 16.

\section{Conclusion}

Quality management starts in the field and continues until produce reaches the end user. The response of fruit and vegetables during storage to postharvest factors in part depends on preharvest practices. Understanding and managing the various roles that preharvest factors play in postharvest quality is very important in order to achieve maximum harvest and postharvest quality. The preharvest treatments had influenced the quality of tomatoes at harvest. The preharvest treatments had also influenced the postharvest quality parameters during storage. Foliar application of $\mathrm{ComCat}^{\left({ }^{B}\right.}$ displayed better maintenance of total soluble solids and ascorbic acid. ComCat ${ }^{\circledR}$ treatment when combined with manure and NP fertilizers had shown lower $\mathrm{pH}$, total soluble solids, titratable acidity and ascorbic acid. Manure treated tomato fruit had higher total total soluble solids, titratable acidity and ascorbic acid. NP fertilizer application resulted in higher titratable acidity. ComCat ${ }^{\circledR}+$ manure and manure maintained ascorbic acid better during storage. ComCat $^{\circledR}$, ComCat $^{\circledR}$ + manure and ComCat ${ }^{\circledR}+$ NP treatments had shown positive effect in keeping weight loss and thus improving the shelf life of tomatoes. Disinfection treatments significantly $(\mathrm{P}<0.05)$ improved marketability of tomatoes during storage. Evaporative cooling positively affected chemical and physiological parameters in tomato fruit and was shown to improve the shelf life of the tomatoes compared to the storage at ambient conditions. This study reveald that integerated agro-technology, combining proper pre- and postharvest treatments, assist in improving the shelf life and maintain chemical quality of tomatoes. 


\section{Aknowledement}

We would like to acknowledge Thomas Huster of Agra Forum Germany for provideing ComCat ${ }^{\circledR}$ and the assistance during the study.

\section{References}

AOAC. 1970. Official Methods of analysis. Assoc. Official Agricultural Chemist. Washington, D.C.

Augustin, J. 1975. Variations in the nutritional composition of fresh potatoes. Journal Food Science 40: 1295-1299.

Booth, R.H. 1978. Post harvest losses and their control. Second regional symposium on pathogens and pests of the potato in the tropics, Baguio city, Philippines. pp.9-18.

Brackett. R.E. 1990. Influence of modified atmosphere packaging on icroflora and quality of fresh bell peppers. Journal of Food Protection 53(3): 255-257.

Brecht, J.K., Bisogini, L. and Mungek, H.M. 1976. Effect of fruit position, stage of ripening and growth habit on chemical composition of fresh tomatoes. Journal of American Society Horticulture Science 41: 945-948.

Cacek, T. and Lagner, L.L. 1986. The economic implications of organic farming. American Journal of Alternative Agriculture 1: 25-29.

Dalal, K.B., Salunkhe, D.K., Boe, A.A. and Olson, L.E. 1965. Certain physiological and biochemical changes in the developing tomato fruit. Journal of Food Science 30: 504-508.

Davies, J.N. and Hobson, G.E. 1971. The Tomato. In: Hulme, A.C. (ed.). The Biochemistry of Fruit and their Products. Vol. 2. Acadamic Press, New York. pp. 438447.

Davies, J.N. and Hobson, G.E. 1981. The constituents of tomato fruit-the influence of environment, nutrition, and genotype. Food Science and Nutrition 15: 205-280.

Duncan, D.B. 1955. New Multiple Range and Multiple Ftests. Biometrics. P.34.

Fallik, E., Grinberg, S., Alkalai, S., Yekutieli, O., Wiseblum, A., Regev, R., Beres, H. and Bar-Lev, E. 1999. A unique and fast postharvest method to improve storage quality of sweet pepper. Postharvest Biolology and Technology 15: 25-32.

Fischer, A.D.A. and Richter, C.H. 1986. Influence of organic and mineral fertilizers on yield and quality of potatoes. In: Proceedings of the Fifth IFOAM Conferences, Germany. p75.

Gomez, K.A. and Gomez, A.A. 1984. Statistical Procedures for Agricultural Research. John Willey and Sons, New York. p390.

Harvey, J.M. 1978. Reduction of losses in fresh fruit and vegetables. Annual Review Phytopathology 16: 321-341.

Hegde, D.M. and Srinivas, K. 1990. Effect of irrigation and nitrogen on yield, nutrient uptake and water use of tomato. Gartenbaumissenschaft 55(4): 173-177.
Hobson, G.E. 1964. Polygalacturonase in normal and abnormal tomato fruit. Journal Biochemistry 92: 324332.

Huster, T. 2001. ComCat ${ }^{\mathbb{R}}$. Personal Communication. Institute of Molecular Physiology and Biotechnology of Plants. University of Bonn. AgraFurum, Germany.

Kader, A.A. 1985. Postharvest biology and technology. An overview In: Postharvest Technology of Horticultural Crops. pp. 3-7.

Karaman, M.R. 1996. Influence of N-fertilizers on the quality of tomato in green-maturity, semired maturity and red-maturity stages. Proceeding of ESNA XXVI ${ }^{\text {th }}$ Meeting, Sept. 12-16.

Koksal, A.L. 1989. Research on the storage of pomegranate (CV. 'Gokbahce') under different conditions. Acta Horticulture 285:795-302.

Lisiewska, Z. and Kmiecik, W. 1996. Effect of level of nitrogen fertilizer, processing conditions and period of storage for frozen broccoli and cauliflower on vitamin C retention. Food Chemistry 57: 267-270.

Mark, R., Steve, S. and Brecht, J. 2003. Preharvest nutrition impacts postharvest quality. American Vegetable Grower 46:26-42.

Maul, F., Sergeant, S.A., Sims, E.A., Baldwin, E.A., Balaban, M.O. and Huber, O.J. 2000. Tomato flavor and aroma quality as affected by storage temperature. Journal of Food Science 65: 1229-1237.

Mccollum, T.G., Chellemi, D.O., Rosskopf, E.N., Church, G.T. and Plotto, A. 2004. Postharvest quality of tomatoes produced in organic and conventional production systems. American Society of Horticulture Science Meeting. Horticultural Science 40(4): 959-963.

Mcdonald, R.E., Mccollum, T.G., and Baldwin, E.A. 1979. Temperature of water heat treatments influences tomato fruit quality following low temperature storage. Postharvest Biolology and Technology 516: 147-155.

Medlicoot, A.P. and Thompson, A.K. 1985. Analysis of sugars and organic acids in ripening fruit by high performance liquid Chromatography. Journal Science of Food and Agriculture 36: 561-566.

Mizrach, A., Filtsanov, U. and Fuchs, V. 1997. An ultrasonic nondestructive method for measuring maturity of fruit. Transaction of American Society of Agricultural Engineering 40: 1107-1111.

Mohammed, M., Wilson, L.A. and Gomes, P.L.1999. Postharvest sensory and physiochemical attributes of processing and non-processing tomato cultivar. Journal of Food Quality 22: 167-182.

Nunes, M.C.N. and Emond, J.P. 1999. Chlorinated water treatments affects postharvest quality of green bell peppers. Journal of Food quality 22: 353-361.

Pal, R.K. and Roy, S.K. 1991. A low cost zero energy cool chambers for short term storage of fruit. Division of fruit and horticultural technology. India Agricultural 
Meaza et al.

Research Institute. New Delhi 110012, India. 291: 23-25.

Prusky, D.S. Halom, Y. and Fuchs, Y. 2001. The level of quiescent infection of alternaira alternate in fruit at harvest determines the postharvest treatment applied for the control of rots during storage. Postharvest Biology and Technology 25: 339-347.

Raupp, J. 1996. Quality of plant products grown with manure fertilization. In comparision of food quality organically versus conventionally grown vegetables. www.eap.mogill.ca/publications/EAP 38.htm. pp. 44-48.

Salunkhe, D.K., Bolin, H.R. and Reddy, N.R. 1991. Storage, Processing, and Nutritional Quality of Fruit and Vegetables. $2^{\text {nd }}$ edition. Vol. I. Fresh Fruit and Vegetables.

Schenabel, H., Roth, U. and Friebe, A. 2000. Brassinosteroids-induced stress tolerances of plants. Recent Res. Developmental Phytochemistry 5: 169-183.

Seyoum, T., Osthoff G., Pretorius J. and Hugo, J. 2003. Comparison of anolyte and chlorinated water as disinfecting treatment for stored carrots. Journal of Food Qualty 26: 463-472.

Seyoum, T. 2002. The improvement of the shelf life of vegetables through pre and post harvest treatment. Ph.D. dissertation presented to the University of Free State. South Africa. P.270.

Seyoum, T. and Woldetsadik, K. 2004. Forced ventilation evaporative cooling of fruits: A case study on Banana, Papaya, Orange, Lemon and Mandarin. Tropical Agriculture Journal 81(3): 179-185.

Tesfaye, K. 2004. Field comparison of resource utilization and productivity of three grain legume species under
East African Journal of Sciences Volume 3 (1) 43-54

water stress. Ph D Thesis presented to Free State University. p.234.

Waskar, D.P, Masalkar, S.P. Gaikward, R.S. and Damgme, S.V. 1991. Effect of Method of harvesting on postharvest loss reduction and extension of shelf life of Fruit. Proceeding of the $5^{\text {th }}$ International Fruit Symposium. Acta Horticulture 2(455): 662-669.

Waskar, D.P., Khedlar, R.M. and Garande, V.K. 1999. Effect of post harvest treatment on shelf life and quality of pomegranate in evaporative cooling chamber and ambient conditions. Jounal Food Science and Technology 2(36): 114-117.

Watada, A.E., Aulenbach, B.B. and Worthington, J.T. 1976. Vitamins A and $C$ in ripe tomatoes as affected by stages of ripeness at harvest and supplementary ethylene. Journal of Food Science 41: 856-858.

Watkins, C.B. and Pritts, M.P. 2001. The influence of cultivars on postharvest performance of fruits and vegetables. Proceedings of the Fourth International Conference on Postharvest Science. Acta Horticulturae 1(553): 59-63.

Winsor, G.W. and Adams, P. 1976. Changes in the composition and quality of tomato fruit throughout the season. Annual Report of Glasshouse Crop Research Institute for 1975. Littlehampton, UK. pp. 134-142.

Yeshida, O., Nakagaua, H., Ogura, N. and Sato, T. 1994. Effect of heat treatment on the development of polygalacturonase activity in tomato fruit during ripening. Plant Cell Physiology 25(3): 500-509. 